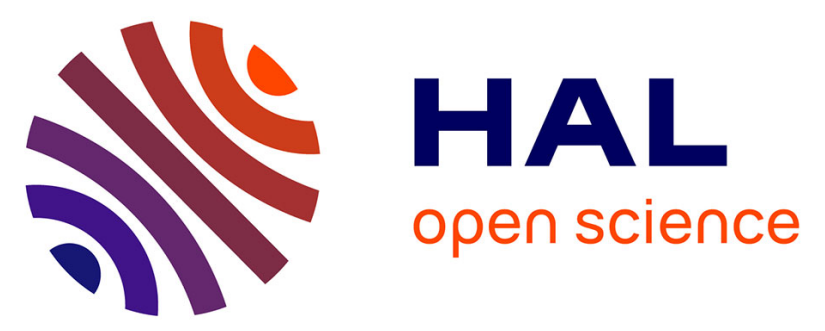

\title{
Karst flow processes explored through analysis of long-term unsaturated-zone discharge hydrochemistry: a 10-year study in Rustrel, France
}

Aurore Perineau Barbel-Périneau, Laurent Barbiero, Charles Danquigny, Christophe Emblanch, Naomi Mazzilli, Milanka Babic, Roland Simler, Vincent Vallès

\section{To cite this version:}

Aurore Perineau Barbel-Périneau, Laurent Barbiero, Charles Danquigny, Christophe Emblanch, Naomi Mazzilli, et al.. Karst flow processes explored through analysis of long-term unsaturatedzone discharge hydrochemistry: a 10-year study in Rustrel, France. Hydrogeology Journal, 2019, 27

(5), pp.1711 - 1723. 10.1007/s10040-019-01965-6 . hal-02082742

\section{HAL Id: hal-02082742 \\ https://hal.science/hal-02082742}

Submitted on 1 Apr 2019

HAL is a multi-disciplinary open access archive for the deposit and dissemination of scientific research documents, whether they are published or not. The documents may come from teaching and research institutions in France or abroad, or from public or private research centers.
L'archive ouverte pluridisciplinaire HAL, est destinée au dépôt et à la diffusion de documents scientifiques de niveau recherche, publiés ou non, émanant des établissements d'enseignement et de recherche français ou étrangers, des laboratoires publics ou privés. 


\title{
Karst flow processes explored through analysis of long-term unsaturated- zone discharge hydrochemistry: a 10-year study in Rustrel, France
}

\author{
Aurore Barbel-Périneau ${ }^{1}$, Laurent Barbiero ${ }^{2}$, Charles Danquigny ${ }^{1,3}$, Christophe Emblanch ${ }^{1}$, \\ Naomi Mazzilli ${ }^{1}$, Milanka Babic ${ }^{1}$, Roland Simler ${ }^{1}$, Vincent Valles ${ }^{1}$ \\ ${ }^{1}$ UMR 1114 EMMAH, Université d'Avignon et des Pays de Vaucluse, INRA, BP 21239, F-84916 Avignon \\ Cedex 9, France \\ ${ }^{2}$ IRD, CNRS, UPS, OMP, Géoscience Environnement Toulouse, 19 Av. E. Belin, 31400 Toulouse, France \\ ${ }^{3}$ TOTAL S.A., CSTJF, Avenue Larribau, 64000 Pau, France \\ *corresponding author
}

\begin{abstract}
The unsaturated zone of karst aquifers influences the dynamics and the chemistry of water. Because of a lack of direct access, other than via caves, flows in the aquifer matrix and the smallest conduits remain poorly characterized. The few artificial underground structures in the unsaturated karst provide a rare opportunity to study the variety of flow processes. At the low noise underground research laboratory (Laboratoire Souterrain à Bas Bruit, LSBB) in Rustrel (France), 12 variables (temperature, $\mathrm{pH}$, electrical conductivity, alkalinity, major anions and cations, total organic carbon) have been monitored on 12 perennial or temporary flows and leakages over a 10-year period covering contrasting climatic periods. This unique dataset of 1,135 samples has been used to discriminate, identify, and rank the processes associated with the hydrochemical variability of these different types of flows. A principal component analysis and a hierarchical cluster analysis, using mean values and standard deviation of the flow along the principal components, were performed. The results indicate that seasonal variability, mean water residence time, and the depth of acquisition of the chemical characteristics are the main factors of the variability of chemistry at the monitored flow points. Distinguished clusters highlight the great diversity of flows and processes occurring in the fine pathways that may be neighboring the large and structured fractures and conduits. Long-term monitoring with various climatic conditions appears to be a useful tool for assessing this diversity.
\end{abstract}

Keywords: Karst, Unsaturated zone, Hydrochemistry, Groundwater monitoring, Groundwater statistics

\section{Introduction}

Karst aquifers differ from other aquifers by their structural, hydrodynamic, and hydrochemical complexity, which are major challenges to sustainable water exploitation and management (Ford and Williams 2007; Goldscheider and Drew 2007). The spatio-temporal heterogeneity of climate input data and of the karst system itself, cause nonlinear flows that are difficult to model (Dreiss 1989). In addition, the processes differ depending on whether they occur in the vadose zone (soil, epikarst and transmission zone) or in the saturated zone (White and White 2005; Williams 1983). For a long time, the transmission zone was considered to be only a transfer layer between the epikarst and the saturated karst. The main reason is the limited ability of researchers to access the diverse flows, which limits direct investigation to stalactite drips (Poulain et al. 2018; Benton and Doctor 2018) and channelled flows (Gabrovšek et al. 2018) in penetrable caves.

The unsaturated zone plays a key role in the karst aquifer dynamics, although its function with respect to transfer and storage is still poorly understood (Carriere et al. 2016; Emblanch et al. 2003; Mudarra and Andreo 2011). The primary factors that promote hydrochemical variability in karst are lithology and soils, pathway type, transfer velocity, and climate conditions (Bakalowicz 1992). 
Hydrodynamics and hydrochemical processes occurring in unsaturated karst are usually characterized indirectly through (1) relationships between input and output hydrological time series (Labat et al. 2000; Ollivier et al. 2015; Guo et al. 2018), (2) integrated hydrogeophysical approaches (Carriere et al. 2016; Vouillamoz et al. 2003; Watlet et al. 2018), (3) deconvolutions from outlet measurements based on physicochemical parameters or isotope ratios (Sánchez et al. 2018; Xiang et al. 2019), and (4) using component-mixing models and hysteresis-loop patterns (Lee and Krothe 2003; Barbieri et al. 2005; Doctor et al. 2006; Toran and Reisch 2013). These kinds of approaches have shown that the dynamics of the main processes at stake (dissolution, precipitation, redox processes) is highly related to hydrodynamic functioning (specific surface of karst conduit, monophasic or diphasic flow, residence time, etc) within the different compartments of the unsaturated zone (soil, epikarst and transmission zone; Vesper and White 2004; Toran and Roman 2006). Recent studies have revealed a diversity of small conduit flows depending mainly on porosity type (fractures, joints, capillary porosity) and the presence or absence of clay deposits, together with variability in possible complex connections between multiple pathways (Aquilina et al. 2006). Because of a lack of direct access other than via caves, flows in the matrix and the smallest conduits remain poorly characterized. In the general context of increasing use of karst aquifers (Mazzilli et al. 2017; Gaillardet et al. 2018; Kazakis et al. 2018; Jourde et al. 2018), it is becoming a priority to better understand the modes of transfer of solutions and solutes within the unsaturated karst, to identify the chemical endmembers and their controlling parameters, and finally to apply this knowledge to outlet deconvolution. Artificial underground environments provide an opportunity for better characterizing flows in matrix and nonpenetrable conduits (Maréchal and Etcheverry 2003; Garry et al. 2008) -for example, investigation in an underground quarry allowed Barhoum et al. (2014) to demonstrate the importance of dissolution, ionic exchange and solute storage.

The objective of this study was to establish a typology of flows in unsaturated karst, including hydrodynamic and hydrochemical characteristics. To this purpose, 10 years of hydrological and hydrochemical monitoring data, acquired at the low noise underground laboratory (LSBB, Laboratoire Souterrain à Bas Bruit) of Rustrel-Pays d'Apt (France), were used. This dataset is unique due to his length over time, the number and variety of flows monitored, and the contrasted climatic periods it covers. The discrimination and ranking of the main factors of chemical variability, their respective sources and associated meaningful hydrochemical processes were based on a multivariate analysis followed by hierarchical clustering from selected characteristics of the principal components (PCs). Then, the aim was to monitor the principal components to identify their possible relationships to unsaturated flow processes with climate variation throughout the monitoring period.

\section{Materials and methods}

\section{Study site}

The study site is located in the catchment area of the Fontaine-de-Vaucluse, Rustrel, France. Fontaine-de-Vaucluse is the most famous karst spring in France and one of the largest. It had an average flow of about $17.5 \mathrm{~m} 3 \mathrm{~S}-1$ between 1966 and 2017, and 14.8 m3 S-1 over the period monitored for this work. Located about $30 \mathrm{~km}$ east of the city of Avignon, Fontaine-de-Vaucluse is the main source of the Sorgues Rivers, which are used for irrigation of the most fertile part of Vaucluse. More information about the Sorgue River station at Fontaine-de-Vaucluse are available (MEDDE 2019). The basin boundaries are not accurately recorded but Fontaine-de-Vaucluse is almost the only spring within a $1,130 \mathrm{~km} 2$ limestone watershed (Puig 1987), which ranges in elevation from 84 to $1912 \mathrm{~m}$ above sea level (asl) (Batiot et al. 2003). 


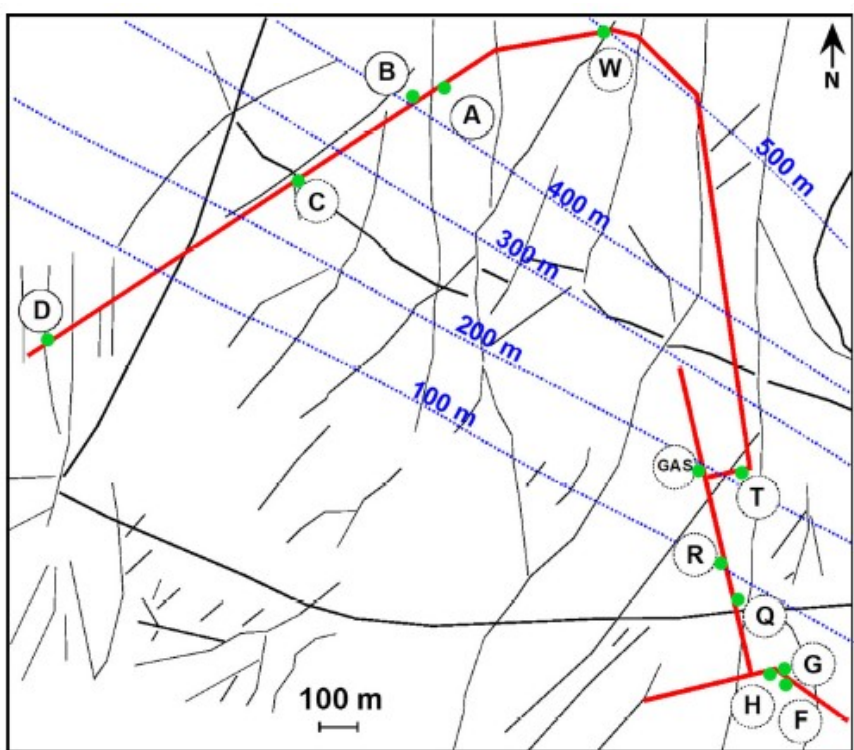

Legend

- Main fault

- Secondary fault

(x) Permanent flow
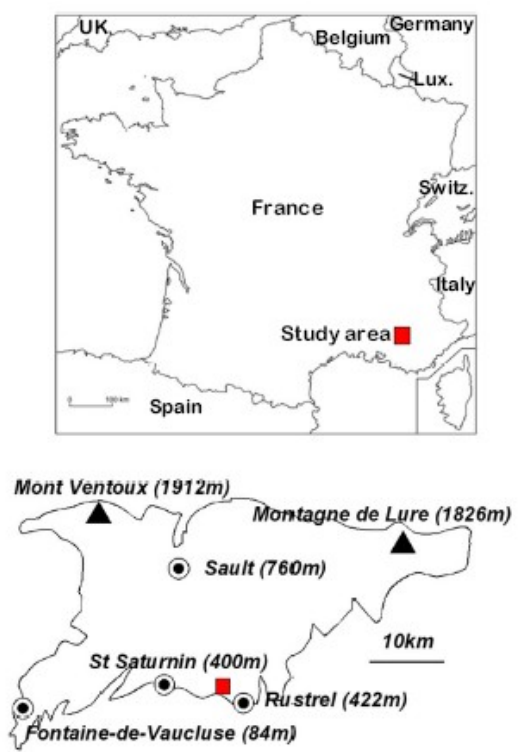

- Study site (LSBB)

Fig. 1 The study site in the gallery of the low noise underground research laboratory (LSBB) in the Fontaine-de-Vaucluse basin, Rustrel, France (note that only the 12 sampling points for which a substantial number of samples were collected are represented)

The aquifer is Early Cretaceous in age and consists of a 1,500-m-thick limestone series between Necomanian marls and Upper Aptian marls (Masse 1967; Tendil et al. 2018). The karst system is composed of a 700-m-thick unsaturated zone on average and at least a 300-m thick saturated zone (Emblanch et al. 2003; Garry et al. 2008). A 3.8-kmlong tunnel within the unsaturated zone, initially dug for military purposes, has been converted into a low noise underground research laboratory known as LSBB (Fig. 1). The tunnel, from 1.7 to $3.7 \mathrm{~m}$ wide, disappears into the massif, and reaches a maximum depth of $519 \mathrm{~m}$ under rock. This easily accessible subterranean space arbitrarily intersects several permanent (3) or temporary (up to 42) flow paths, thus providing an unusual opportunity for access to a variety of flows through the vadose zone. Lithological and geotechnical surveys along the tunnel are based on observations noted during initial drilling that pointed out lithology, faults, joints, cracks, karstification and seepage points. Fracture frequency and thickness of overlying rock at each flow point were calculated (Garry et al. 2008). Assessment of the hydrogeological context of the shallowest flow point (permanent flow point D) was achieved using surface-based hydrogeophysical approaches (Carriere et al. 2016). Characterization of other flow points, using such an approach, remains out of reach because of steep slope and thickness of the rock cover. Typology of the flows was undertaken by Garry et al. 2008 based on a reduced dataset (only five active flow points during this 3-year monitoring). Subsequent study (Barbel-Perineau et al. 2015) benefited from monitoring of up to 45 flow points due to wet conditions during hydrological year 2008-2009. Qualitative analysis led to a three-class typology based on flow duration.

\section{Data collection}

Flow monitoring started in February 2002 and continued for 10 years until January 2012. This monitoring period was marked by several climatic periods, including, firstly, a dry period from May 2004 to May 2008 marked by a severe rainfall deficit, with about 
910 and 2,370 $\mathrm{mm}$ of effective and bulk rainfall, respectively, over 4 years. This rainfall is about $50 \%$ of average the regional rainfall. The lowest daily discharge flow since $1966\left(2.74 \mathrm{~m}^{3} \mathrm{~s}^{-1}\right)$ was recorded at the outlet (Fontaine-de-Vaucluse) on November 18, 2007. The other remaining three climatic periods are (1) a recovery period from June 2008 to November 2009 characterized by much higher rainfall than the previous period, totaling about 670 and $1300 \mathrm{~mm}$ of effective and bulk rainfall over 18 months; (2) a wet period from December 2009 to January 2011 marked by significant rainfall, with about $490 \mathrm{~mm}$ of effective rainfall over 13 months; (3) a short dry period from February 2011 to September 2011 with 61 and $390 \mathrm{~mm}$ of effective and bulk rainfall. The three permanent flows (referred as $A, B$, and $D$ ) and two temporary flows ( $C$ and GAS) have been observed and monitored since 2002. Other temporary flows (40) were identified during the high rainfall period in winter 2008.

Monitoring consisted of 267 field campaigns irregularly distributed over a 10-year period. Beginning in September 2003, each flow point was drilled and water inflows were directed into a spillway with a funnel to facilitate discharge measurements. Discharges were measured manually at the outlet of the collecting funnel using a 100$\mathrm{ml}$ measuring cylinder. Temperature $\left(\mathrm{T}^{\circ} \mathrm{C}\right), \mathrm{pH}$, and electrical conductivity (EC) were measured in situ. Water samples were collected in duplicate and stored in the dark and at $4{ }^{\circ} \mathrm{C}$ in a previously acid-washed container. Other analyses were performed in the laboratory. Alkalinity was measured by $0.02 \mathrm{~N} \mathrm{H}_{2} \mathrm{SO}_{4}$ titration and other major anions $\left(\mathrm{Cl}^{-}, \mathrm{SO}_{4}{ }^{2-}, \mathrm{NO}_{3}{ }^{-}\right)$and cations $\left(\mathrm{Ca}^{2+}, \mathrm{Mg}^{2+}, \mathrm{Na}^{+}, \mathrm{K}^{+}\right)$by ion chromatography (Dionex DX 120). Traces of $\mathrm{F}^{-}, \mathrm{Br}^{-}, \mathrm{NO}_{2}{ }^{-}$, and $\mathrm{NH}_{4}{ }^{+}$close to the detection limit were observed but not used in this study. Samples for total organic carbon (TOC) were also collected in previously acid-washed $\left(0.1 \mathrm{~N} \mathrm{HNO}_{3}\right)$ and combusted $\left(550{ }^{\circ} \mathrm{C}\right)$ glass bottles - analysis was performed by combustion (Aurora 1030, I-O Analytical - and all uncertainties were below $5 \%$.

\section{Data treatment}

The 45 discharge sampling points provide a wide range of flow rates and flow durations. This study covers almost 10 years of monitoring from 2002 to 2012, and 12 flows for which a substantial number of samples were collected. The flows are referred to alphabetically, with the number of samples in parentheses: A (267), B (267), C (154), GAS (44), D (254), and also $G, H, Q, R, T, W, F$ (from 10 to 48 samples each). Field pH values were transformed into $\mathrm{H}_{+}$activities to obtain a homogeneous set of parameters with $\mathrm{H}_{+}, \mathrm{EC}$ and other water quality parameters. The total dataset consists of 12 variables ( $\mathrm{Ca}, \mathrm{Na}, \mathrm{Mg}, \mathrm{K}, \mathrm{Cl}, \mathrm{SO}_{4}, \mathrm{NO}_{3}$, Alk (carbonate alkalinity), $\mathrm{TOC}, \mathrm{EC}, \mathrm{H}$, and $\mathrm{T}^{\circ} \mathrm{C}$ ) and 1,135 observations, whereby variables were significantly above detection limits for all observations, and, given the $\mathrm{pH}$ range of the dataset, the carbonate alkalinity was considered only as $\mathrm{HCO}_{3}{ }^{-}$. A principal components analysis (PCA) was performed by diagonalization of the correlation matrix to identify, quantify, and rank the variability factors and to explore the underlying processes affecting water chemistry (MS Excel software XLSTAT 2011 v2.08, Addinsoft, Paris, France). The procedure includes variable mean centering, which sidestepped problems arising from the variable numerical ranges and units used by automatically autoscaling all variables to the mean zero and variance unit. The PCA procedure transforms $n$ original variables into $n$ orthogonal principal components (PCs) that are a linear combination of the original variables, whereby the orthogonal (uncorrelated) principal components ensure the independence of associated processes.

The $\mathrm{CO}_{2}$ partial pressure was calculated using the AQUA ion pair model (Valles et al. 1996). The $\mathrm{pH}$ values were acquired in the field during sampling. Assuming that the alkalinity does not change from the field to the analysis, the calculated $\mathrm{pCO}_{2}$ corresponds to field conditions; however, $\mathrm{pCO}_{2}$ was not included as a variable in the PCA because it derives mainly from $\mathrm{pH}$ and alkalinity. Considering $\mathrm{pCO}_{2}$ as a variable in the same way as other major ions would result in an artificial reinforcement of its weight on the total sampling variance (Rezende-Filho et al. 2015). The treatment was 
carried out on the entire dataset ( 1,135 samples, $n=12$ variables) to identify the main variables and samples responsible for chemical variability, with PCA principal components being referred to as $U_{1}, U_{2}, \ldots U_{12}$. The position of the variables in the main score plots was used to identify processes associated with the primary principal components based on hydrochemical criteria. Then, a hierarchical cluster analysis was performed using mean values and standard deviation of the flow along the principal components. Relative similarities between flows were quantified using the Euclidean distance (MS Excel software XLSTAT 2011 v2.08). The levels of similarity at which observations are merged were used to construct a dendrogram.

Table 1 Descriptive statistics of major ions, total organic carbon, electrical conductivity, and temperature (T). SD standard deviation, CoV coefficient of variation

\begin{tabular}{|c|c|c|c|c|c|c|}
\hline Parameter & Unit & Min. & Max. & Mean value & SD & $\mathrm{CoV}$ \\
\hline $\mathrm{T}^{\circ} \mathrm{C}$ & ${ }^{\circ} \mathrm{C}$ & 10.5 & 15.6 & 12.78 & 0.58 & 0.05 \\
\hline $\mathrm{H}^{+}$ & $\mathrm{mmol} \mathrm{l}^{-1}$ & $1.510^{-9}$ & $2.2410^{-7}$ & $2.1410^{-8}$ & $1.7210^{-8}$ & 0.81 \\
\hline $\mathrm{EC}$ & $\mu \mathrm{S} \mathrm{cm}{ }^{-1}$ & 183 & 623 & 402 & 53.9 & 0.13 \\
\hline $\mathrm{HCO}_{3}{ }^{-}$ & $\mathrm{mmol} \mathrm{l}^{-1}$ & 1.75 & 6.75 & 4.02 & 0.69 & 0.17 \\
\hline $\mathrm{C \Gamma}$ & $\mathrm{mmol} \mathrm{l}^{-1}$ & 0.01 & 0.43 & 0.14 & 0.03 & 0.23 \\
\hline $\mathrm{NO}_{3}^{-}$ & $\mathrm{mmol} \mathrm{l}^{-1}$ & $510^{-7}$ & 0.47 & 0.02 & 0.02 & 0.94 \\
\hline $\mathrm{SO}_{4}{ }^{2-}$ & $\mathrm{mmol} \mathrm{l}^{-1}$ & $510^{-8}$ & 0.25 & 0.05 & 0.03 & 0.72 \\
\hline $\mathrm{Ca}^{2+}$ & $\mathrm{mmol} \mathrm{l}^{-1}$ & 0.08 & 3.22 & 1.93 & 0.33 & 0.17 \\
\hline $\mathrm{Mg}^{2+}$ & $\mathrm{mmol} \mathrm{l}^{-1}$ & 0.01 & 0.43 & 0.11 & 0.08 & 0.76 \\
\hline $\mathrm{Na}^{+}$ & $\mathrm{mmol} \mathrm{l}^{-1}$ & $310^{-6}$ & 0.28 & 0.09 & 0.02 & 0.26 \\
\hline $\mathrm{K}^{+}$ & $\mathrm{mmol} \mathrm{l}^{-1}$ & $110^{-7}$ & 0.22 & $910^{-6}$ & 0.02 & 1.66 \\
\hline TOC & $\mathrm{mg} / 1$ & 0.51 & 32.56 & 1.40 & 1.31 & 0.93 \\
\hline
\end{tabular}

\section{Results and discussion}

Descriptive statistics for the entire dataset are shown in Table 1. Water electrical conductivity ranged from 183 to $623 \mu \mathrm{S} \mathrm{cm}{ }^{-1}$. The most highly mineralized waters clearly showed a $\mathrm{Ca} / \mathrm{HCO}_{3}$ chemical profile. The most pronounced variations observed are those for $\mathrm{K}^{+}$and TOC. Contribution of principal components to total variance is presented in Table 2 . About $54 \%$ of the variance is distributed around three main axes, with contributions of $24.4,16.1$, and $14 \%$, respectively.

The four primary principal components $\left(U_{1}-U_{4}\right.$; Table 2$)$ have eigenvalues higher than unity, indicating that they contain more information than one original variable (Helena et al. 2000). Principal components $U_{4}-U_{6}$ show a contribution ranging from 7.3 to $9.7 \%$, indicating that the chemical composition variability of all flows and variables cannot be summarized by only a few major processes. A significant number of processes have comparable intensities, i.e., the dataset is rich with information; however, principal components $\mathrm{U}_{4}$ and above account for a percentage less than $10 \%$, which makes it difficult to distinguish an associated process. Therefore, these principal components were not considered in the study due to their low eigenvalues, assuming that they make up part of the chemical background noise of the sample set (Rezende-Filho et al. 2015; Helena et al. 2000).

Distribution of variables in score plots $U_{1}-U_{2}$ and $U_{1}-U_{3}$

$\mathrm{U}_{1}$ is dominated by positively correlated variables, primarily EC, Alk, and Ca and slightly negatively correlated with $\mathrm{NO}_{3}$ and $\mathrm{SO}_{4}$ (Fig. 2a). Electrical conductivity has the highest weight; thus, the overall amount of dissolved ions is the primary variable in flow chemistry, and $\mathrm{U}_{1}$ can be considered as a PC of water mineralization, influenced mainly by calcite dissolution. It can be noted that $M g$ contributes little to $U_{1}$, whereas the 
contribution of temperature $\mathrm{T}\left({ }^{\circ} \mathrm{C}\right)$ is not negligible; thus, $\mathrm{U}_{1}$ seems to be strongly influenced by seasonal variability.

$\mathrm{U}_{2}$ is positively scored with $\mathrm{Mg}$, and negatively scored with $\mathrm{SO}_{4}$. The variability of $\mathrm{Mg}$ cannot be explained by lithological heterogeneity because the bedrock does not show dolomitic facies (Masse 1967); however, due to its slower dissolution kinetics than calcium, magnesium (or $\mathrm{Mg} / \mathrm{Ca}$ ratio) has been recognized as a useful qualitative indicator of water residence time in the aquifer (Batiot et al. 2003; Moral et al. 2008). The interpretation is more delicate concerning the $\mathrm{SO}_{4}$ variable. Isotopic studies carried out in a karst system in southern Germany show that in addition to atmospheric deposition, mineralization of carbon-bonded $S$ in the vadose zone may give rise to sulfate (Einsiedl and Mayer 2005, 2006). Bacterial dissimilatory sulfate reduction occurring in the karst matrix may be responsible for decreased sulfate concentration (Einsiedl and Mayer 2005; Strebel et al. 1990) in waters with long residence time, over 50 years. Mean residence time estimated for flow points A, B, C, D, GAS based on TOC and dissolved organic matter transit time tracers (Blondel et al. 2010; Garry et al. 2008) are less than 1 year, which therefore limits the possibility of sulfate reduction in these aerated environments. Compatibility of the flow dynamics with bacterial sulfate reduction thus remains to be established. Still, the negative correlation between $\mathrm{Mg}$ and $\mathrm{SO}_{4}$, along $\mathrm{U}_{2}$ suggests that this $\mathrm{PC}$ reflects the water residence time in the aquifer. The axis of the third PC $\left(\mathrm{U}_{3}\right)$ discriminated waters particularly rich in $\mathrm{Na}$ and $\mathrm{K}$ (Fig. $2 \mathrm{~b}$ ). This may reflect a superficial origin of the water chemical characteristics, in contrast with waters whose chemical acquisition occurs deeper, and that are more clearly with an $\mathrm{HCO}_{3}-\mathrm{Ca}$ profile.

Because the principal components behave like synthetic hydrochemical macro parameters, it is possible to study their relationship to the flow rate and in particular to hysteresis patterns. The example given in Fig. 3 shows flow A for a 2-month period from November 5, 2003 to January 7, 2004, wherein U1 shows a clockwise hysteresis. Such hysteresis is expected for principal components primarily influenced by chemical elements derived from bedrock (Evans and Davies 1998).

Table 2 Principal components, contributions to variance and eigenvalues

\begin{tabular}{llll}
\hline Principal component & Contribution to variance (\%) & Cumulate contribution (\%) & Eigenvalue \\
\hline $\mathrm{U}_{1}$ & 24.37 & 24.37 & 2.92 \\
$\mathrm{U}_{2}$ & 16.12 & 40.49 & 1.93 \\
$\mathrm{U}_{3}$ & 13.99 & 54.47 & 1.68 \\
$\mathrm{U}_{4}$ & 9.70 & 64.18 & 1.17 \\
$\mathrm{U}_{5}$ & 8.06 & 72.24 & 0.96 \\
$\mathrm{U}_{6}$ & 7.26 & 79.51 & 0.87 \\
$\mathrm{U}_{7}$ & 6.92 & 86.43 & 0.83 \\
\hline
\end{tabular}

Figure 4 shows the evolution of the calculated $\mathrm{pCO}_{2}$ during the collection period. Seasonality of $\mathrm{CO}_{2}$ partial pressures increasing during the summer and decreasing in winter, as already observed by many authors (Covington and Vaughn 2018), is clearly seen during standard and dry periods. It is made less visible during wet periods due to dilution effect; moreover, it was observed that the fluctuations of $\mathrm{pCO}_{2}$ closely accompany the fluctuations of $\mathrm{U}_{1}$. All these observations suggest that the principal component $U_{1}$ is primarily influenced by calco-carbonic equilibrium and seasonal variability of $\mathrm{pCO}_{2}$ in soil causing variable mineralization of infiltrated water. During the period under consideration, from November to January, water that infiltrated in winter, when soil $\mathrm{pCO}_{2}$ is relatively low, replaced water that infiltrated in summer when soil $\mathrm{pCO}_{2}$ is relatively high (Toran and Roman 2006). While $\mathrm{U}_{2}$ does not show a clear trend 
(not shown), $U_{3}$ presents an anticlockwise hysteresis, suggesting a predominant influence of soluble ions and from near surface sources (Toran and Reisch 2013).

\section{Impact of the water mineralization}

The distribution of observations in the $U_{1}-U_{2}$ scores plot is presented in Fig. 5 . It is possible to discern various flows, which exhibited a pronounced temporal variability throughout the 10-year collection period. Most flows show a high variability in water electrical conductivity (EC), which is reflected by elongated plots along $U_{1}$. This trend is clear for four groups of flows with increasing variability in mineralization: (1) D, (2) A and $B,(3)$ C, Q, R and W, and (4) GAS and T. Higher variability of the latter may be interpreted as an increased sensitivity of water mineralization to climate conditions, and thus lower buffer effect, possibly due to fast transfer paths within the surrounding rock. By contrast, for flow $\mathrm{D}$, the low dilution of its mineralization during rainy periods reflects a strong inertia along $\mathrm{U}_{1}$. Furthermore, flows $\mathrm{F}, \mathrm{G}$ and $\mathrm{H}$ display a higher average mineralization, which distinguishes them from other flows.
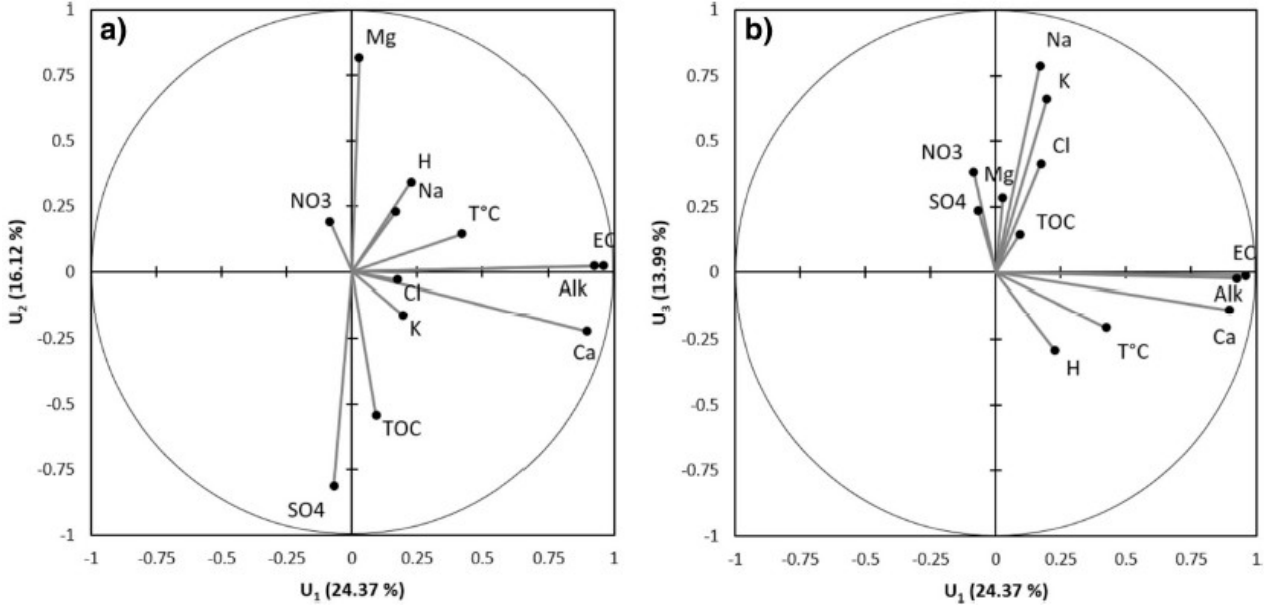

Fig. 2 Variable distribution in scores plots a $U_{1}-U_{2}$ and $b U_{1}-U_{3}$ for principal component analysis of the entire dataset (1,135 observations)
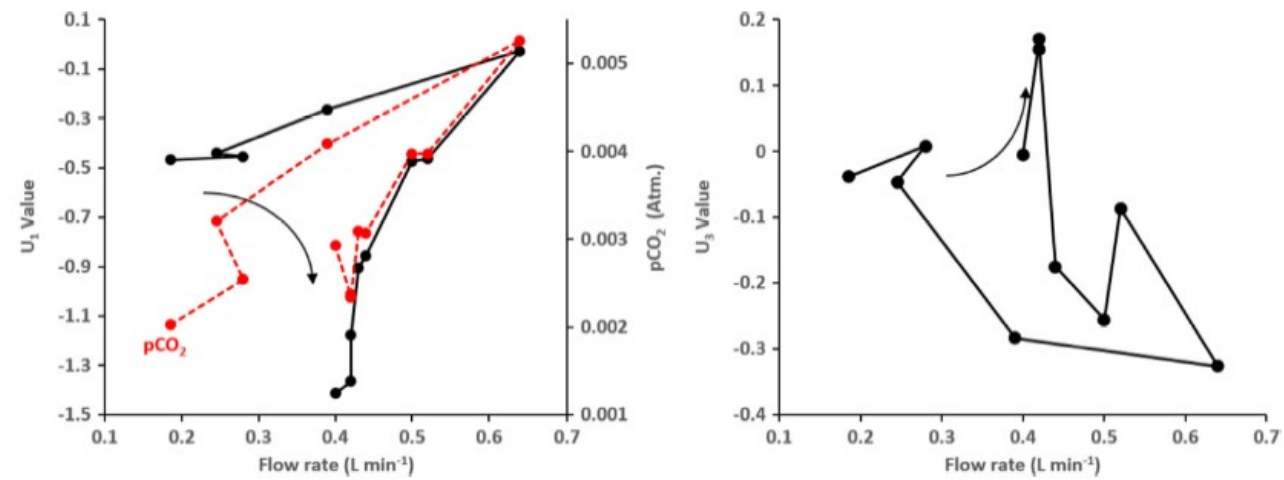

Fig. 3 Principal components $U_{1}$ (together with pCO2) and $U_{3}$ versus flow rate hysteresis for flow A during a 2-month period from November 5, 2003 to January 7, 2004

$\mathrm{U}_{1}$ appears to be an indicator of the stability of flow chemistry. The more a plot is scattered along the $U_{1}$ axis, the more sensitive the flow is to seasonal climatic variations, possibly reflecting rapid transfer down to the sampling point. Indeed, flow point GAS is located in a fractured area showing an important karstification. In contrast, permanent flow at $A, B, D$ and sustained recession of $D$ and $A$ show the importance of matrix contribution to these flows. Figures 6 and 7, showing the monitored period for 
permanent flows $A$ and $D$, illustrate this difference in behavior. While flow $A$ shows strong seasonal variations of parameter $U_{1}$, these variations are much less obvious for flow $D$. At the same time, the flow rate of $A$ is highly variable over time, whereas that of $\mathrm{D}$ is much more stable and regular. Therefore, it appears that the flow dispersion along this axis $U_{1}$, which can be evaluated from the standard deviation of the scatter plot, is a relevant criterion for the flow discrimination. Both the mean value and standard deviation of each flow along $U_{1}$ will be used below for a hierarchical clustering.

\section{Discrimination from residence time using $\mathrm{U}_{2}$}

The flow occurrences for A, B, C, D, GAS and W, with a significant number of samples, are reported as a histogram along the PC U2 (Fig. 8). Thus, regardless of their sensitivity to seasonal climatic variations, it is possible to discriminate flows as a function of residence time, which increases with increasing coordinate along $U_{2} ; A$ and $B$ appear relatively similar, although they are distinct and have partially overlapping histograms. These drip water points are supplied by very slow flow, characterized by higher magnesium and lower organic carbon contents. Flows $\mathrm{D}$ and $\mathrm{W}$ are in intermediate positions, with low $\mathrm{Mg}$ and TOC values. For these waters, residence time is long enough to allow organic matter to decompose and for a decrease in TOC values. Flows $\mathrm{C}$ and GAS show the lowest values along $U_{2}$ and thus reflect fast water circulation down to the drip water point. These results are consistent with previous ones obtained by Garry et al. (2008) and Barbel-Perineau et al. (2015). The mean value of the coordinate along $U_{2}$ will be the third criterion used for hierarchical clustering of flows.

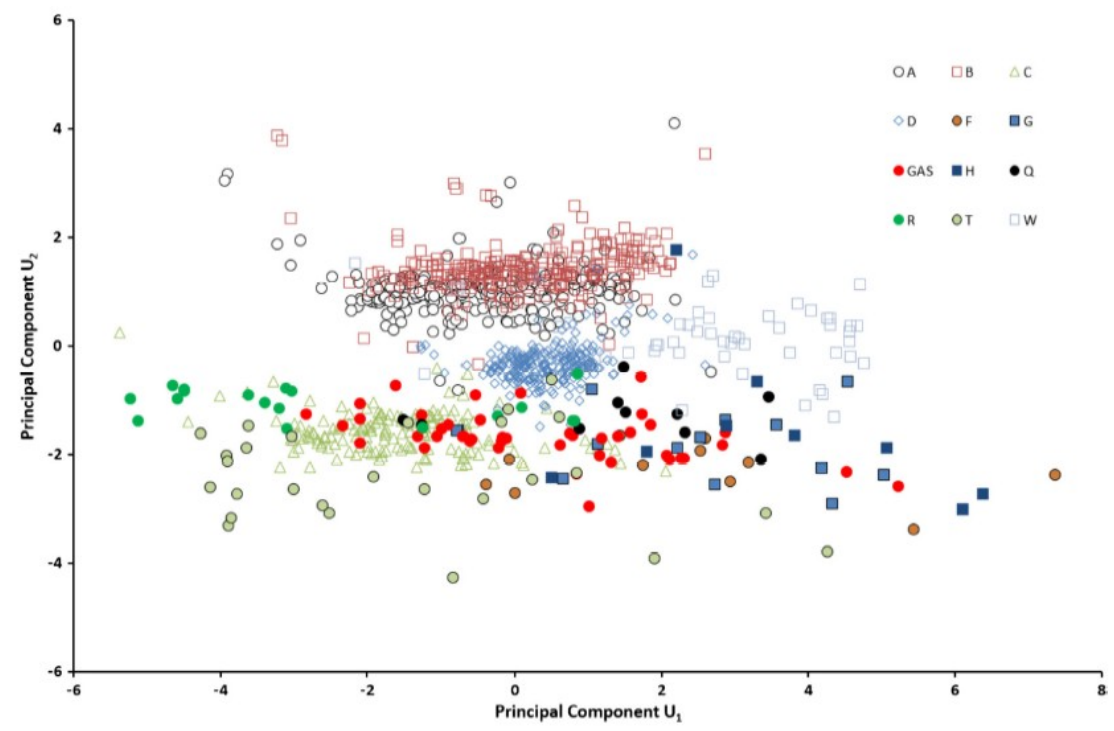

Fig. 5 Distribution of the observations in the scores plot U1-U2 (12 flows, 1,135 observations) 


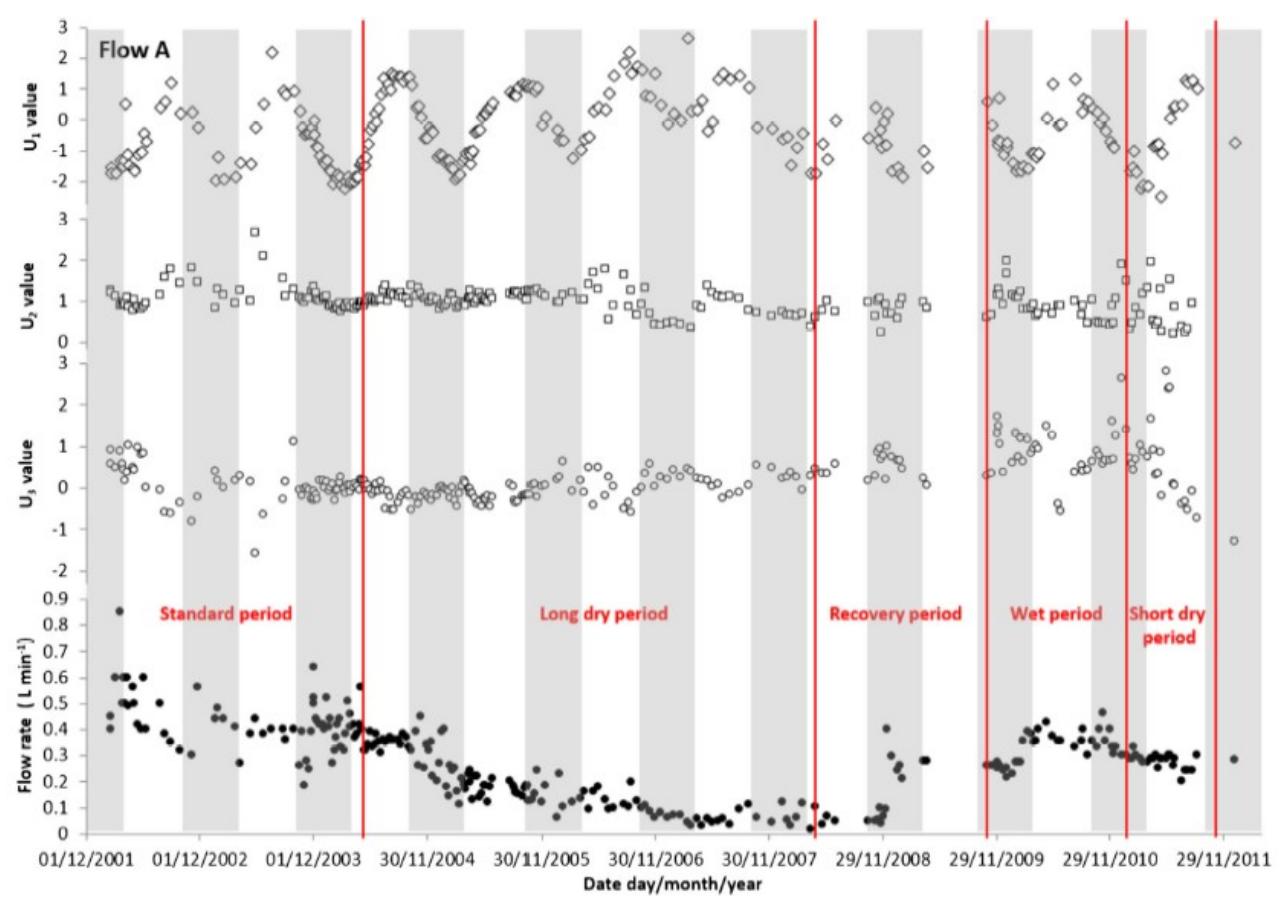

Fig. 6 Flow rate and parameters U1, U2 and U3 for flow A throughout the 10-year period of data collection

\section{Flow discrimination in the second scores plot $\mathrm{U}_{1}-\mathrm{U}_{3}$}

The third principal component $U_{3}$ is not as useful as $U_{2}$ in discriminating flows; however, it discriminates flows as a function of the origin of water chemistry, i.e. whether the acquisition of chemical characteristics took place in contact with topsoil horizons, or in contact with bedrock. This principal component makes it possible to discriminate temporary flows T, G, F and possibly $\mathrm{H}$ as having chemical characteristics episodically influenced by surface horizons from the rest of the samples, which have a much deeper chemical signature (Fig. 9). The discrimination is based primarily on higher contents of $\mathrm{Na}^{+}, \mathrm{K}^{+}$and $\mathrm{Cl}^{-}$, but also TOC and $\mathrm{SO}_{4}{ }^{2-}$ values, and secondarily $\mathrm{NO}_{3}{ }^{-}$. The mean value of the coordinate along $U_{3}$ will be the last criterion used for a hierarchical clustering of flows.

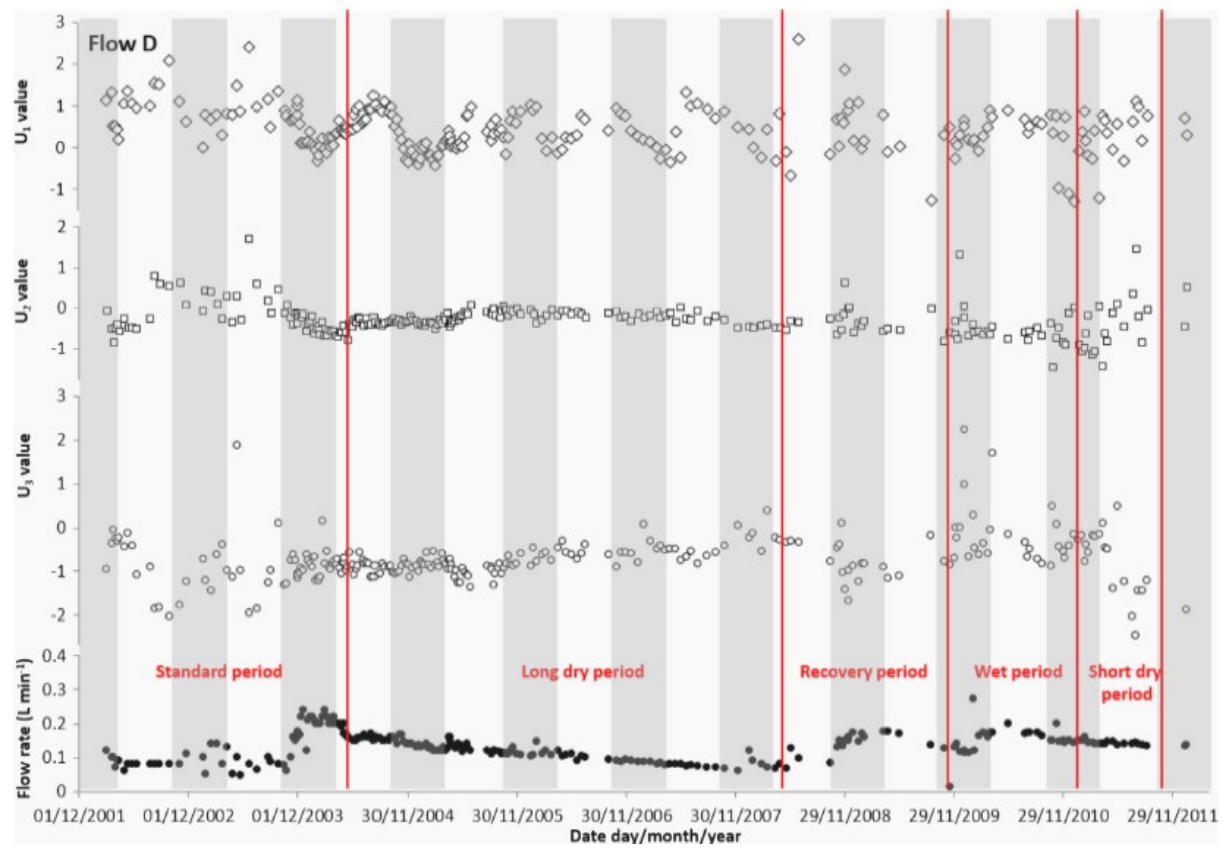


Fig. 7 Flow rate and parameters U1, U2 and U3 for flow D throughout the 10-year period of data collection

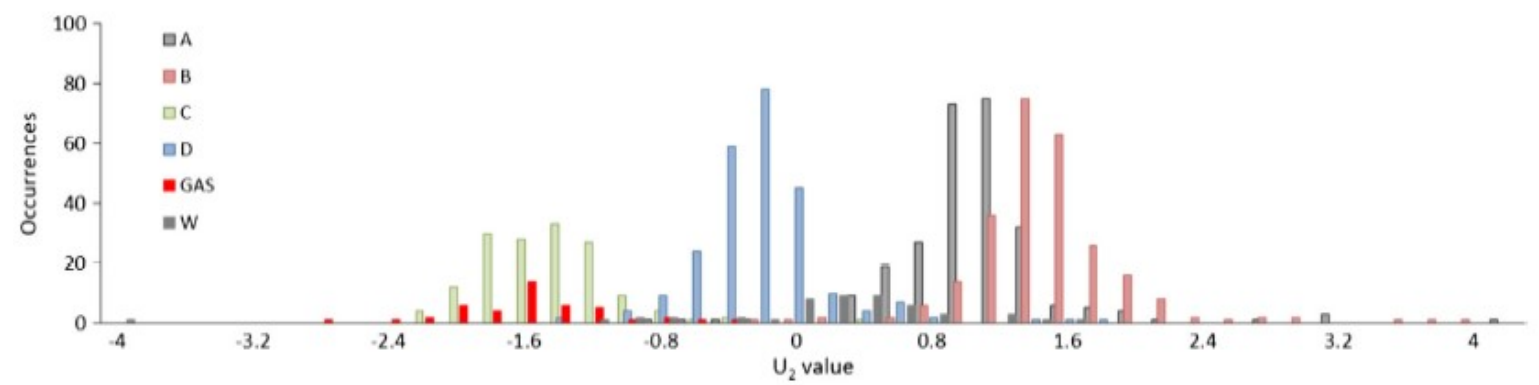

Fig. 8 Histogram of flow occurrences along principal component U2

\section{Hierarchical clustering of flows}

This study highlights four chemical criteria to distinguish flows and to establish a classification. These criteria reflect mineral load, chemical sensitivity to seasonal variations, chemical changes associated with water residence time, and the surface or deep origin of flow chemistry; however, these criteria derive from the principal components that account for the total variability of sampling in different proportions. Therefore, the criteria were weighted by the eigenvalue associated with the corresponding principal component; thus, mean and standard deviation of each flow along $U_{1}$ were weighted by the eigenvalue associated with $U_{1}$, and average coordinates of flows along the $\mathrm{U}_{2}$ and $\mathrm{U}_{3}$ axes were weighted by their respective eigenvalues (Table 2 ). Figure 10 presents the dendrogram obtained from hierarchical clustering of flows based on those weighted criteria. Four groups were discriminated, highlighted by the dashed phenom line, whereby the results show close grouping of A and B (group 1) having an intermediate mineral load and a moderate chemical change throughout the season, suggesting a similar or common source and pathway. Both flow have higher coordinates along $U_{2}$ (Fig. 8), i.e. a longer residence time. Group 2 consists of $C$, $R$ and $\mathrm{T}$ mainly characterized by lower coordinate along $U_{2}$, i.e. rapid flows with short residence time, but also lower mineral load. Other flows were further split into two groups. Group 3 consists of flows with low or moderate residence time but moderate (D) to higher (Q, GAS, W) mineral load. In contrast, the last group (group 4) is composed of very temporary flows $\mathrm{F}, \mathrm{G}$ and $\mathrm{H}$, located close together, and close to the entrance of the tunnel, i.e. under a low thickness of rock of about $65 \mathrm{~m}$. Despite a short residence time, these flows have a high mineral charge, and, logically, a chemistry influenced by the superficial part of the epikarst. Although $G$ and $H$ have a similarity close to 1 , their distance of about $13 \mathrm{~m}$, makes unlikely a double intersection of the same flow by the tunnel. 


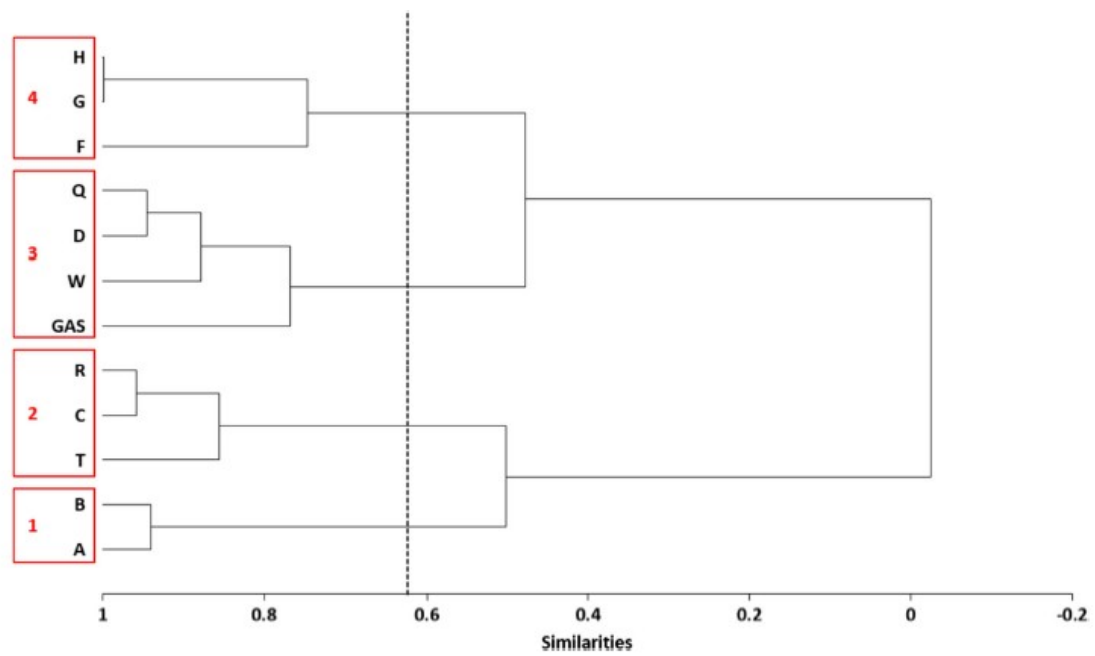

Fig. 10 Dendrogram obtained from hierarchical cluster analysis of weighted criteria reflecting mineral charge, seasonal chemical stability, residence time, and origin of flow chemistry

\section{Parameters evolution throughout 10 years of data collection}

Figures 6 and 7 show the evolution of parameters $U_{1}, U_{2}$ and $U_{3}$ throughout the collection period for flows $A$ and $D$. Although not very pronounced, some trends can be noted; as mentioned previously, the seasonality of $U_{1}$ is much more marked for flow $A$ than for flow D. Flow A behaviour is quite typical of karst flows, while the steadier hydrodynamic behavior of $D$ is less usual in karst. A better understanding of the latter was provided by an integrated hydrogeophysical approach (Carriere et al . 2016) . Surface-based hydrogeophysical investigations performed from above point $D$ evidenced the high free water content (up to 10\%) within Urgonian limestones on that test site. This large porosity of the limestone matrix was associated with crossstratification features which are typical of high-energy and thus usually porous deposits. During the long dry period of 2004-2008 and for A, minimum values of $U_{1}$ increase, reflecting a decrease in the proportion of rapid flows due to reduced number and magnitude of rainfall events, and thus of dilution of winter water.

This trend, not detected for $D$ due to higher buffering effect, on $U_{3}$, reflecting a decrease in the residence time because of decreased buffering effect due to drought. This trend is clearer for $D$ than for $A$; indeed, higher buffering effect for point $D$ allows to better assess pluri-annual effects, while behaviour of point $A$ is more typical of karst systems with a higher reactivity to rainfall. Dispersion of $U_{1}$ and $U_{3}$ increased during wet periods for both $A$ and $D$ flow points, due to increased magnitude and variability of rainfall.

\section{Conclusion}

The originality of this study lies in two original aspects: on the one hand, the nature of the data-namely, direct access to flows in unsaturated karst and to their diversityand on the other hand, the collection time itself, which spanned over 10 years. Multivariate analysis made it possible to discriminate, identify, and rank the processes associated with the hydrochemical variability of these different types of flows. This highlights four criteria, whose impact varies according to the flows considered, therefore allowing the setup of a classification. These criteria are water mineralization, chemical sensitivity to seasonal fluctuation, water residence time, and surface versus deep origin of the acquisition of water chemical characteristics. The study confirms that unsaturated karst cannot be considered as a simple transfer zone to saturated karst without influence on the chemistry of the waters. In addition to large, structured, connected fractures and conduits, great diversity exists within a network of fine 
pathways. Long-time collection such as that currently conducted at the low noise underground research laboratory LSBB, is essential for a consistent and robust assessment of the processes at stake and of their weight in hydrochemical variability. This analysis was mainly based on the hydrochemical characteristics of the flows, but knowledge regarding this karst system could be further improved by consideration of hydrodynamic behaviour, and by considering the influence of rainfall and saturation state of the system on observed variability. Knowledge of the main processes identified in this study, and their seasonal or inter-annual hydrochemical variations, will first benefit the analysis of the flow at the outlet of the karst system, the Sorgue River, but it could also be used in the medium term for deconvolution at other sites with similar lithological contexts.

Acknowledgements: The authors thank LSBB (University of Nice, University of Avignon, CNRS, AixMarseille University, OCA - http://www.lsbb.eu) and all the LSBB team for their technical and logistic help. Part of the hydrochemical analyses used in this study were founded by the network of hydrogeological researches sites $\mathrm{H}^{+}$(http://hplus.ore.fr/). This work also benefited from fruitful discussion within the KARST observatory network (SNO KARST) initiative from the INSU/CNRS. SNO KARST aims to strengthen knowledge sharing and to promote cross-disciplinary research on karst systems at the national scale.

\section{References}

Aquilina, L, B Ladouche, and N Dörfliger. 2006. "Water Storage and Transfer in the Epikarst of Karstic Systems during High Flow Periods.” Journal of Hydrology 327 (3-4): 472-85. https://doi.org/http://dx.doi.org/10.1016/j.jhydrol.2005.11.054.

Bakalowicz, M. 1992. "Géochimie Des Eaux et Flux de Matière Dissoutes, Approche Objectif Du Rôle Du Climat Dans La Karstogénèse.” In Karst et Évolution Climatique, edited by J N Salomon and R Maire, 61-74. Presses Universitaires de Bordeaux.

Barbel-Perineau, A, C Emblanch, and C Danquigny. 2015. "Spatial and Temporal Hydrodynamic Variations of Flow in the Karst Vadose Zone (Rustrel, France) in Function of Depth and Fracturing Density.” In Hydrogeological and Environmental Investigations in Karst Systems, edited by Bartolomé Andreo, Francisco Carrasco, Juan José Durán, Pablo Jiménez, and James W LaMoreaux, 11-18. Berlin, Heidelberg: Springer Berlin Heidelberg. https://doi.org/10.1007/978-3-642-17435-3_2.

Barbieri, M, T Boschetti, M Petitta, and M Tallini. 2005. "Stable Isotope (2H, $18 \mathrm{O}$ and 87Sr/86Sr) and Hydrochemistry Monitoring for Groundwater Hydrodynamics Analysis in a Karst Aquifer (Gran Sasso, Central Italy)." Applied Geochemistry $20 \quad$ (11): 2063-81. https://doi.org/http://dx.doi.org/10.1016/j.apgeochem.2005.07.008.

Barhoum, S, D Valdès, R Guérin, C Marlin, Q Vitale, J Benmamar, and P Gombert. 2014. "Spatial Heterogeneity of High-Resolution Chalk Groundwater Geochemistry - Underground Quarry at Saint Martin-Le-Noeud, France." Journal of Hydrology 519: 756-68. https://doi.org/https://doi.org/10.1016/j.jhydrol.2014.08.001.

Batiot, C, C Emblanch, and B Blavoux. 2003. "Carbone Organique Total (COT) et Magnésium (Mg2+): Deux Traceurs Complémentaires Du Temps de Séjour Dans l'aquifère Karstique.” Comptes Rendus Geoscience 335 (2): 205-14. https://doi.org/10.1016/S1631-0713(03)00027-0.

Benton, J R, and D H Doctor. 2018. "Investigating Vadose Zone Hydrology in a Karst Terrain Through Hydrograph and Chemical Time-Series of Cave Drips at Grand Caverns, Virginia.” In Proceedings of the 15th Multidisciplinary Conference on Sinkholes and the Engineering and Environmental Impacts of Karst and the 3rd Appalachian Karst Symposium. https://doi.org/10.5038/9780991000982.1030. 
Blondel, T, C Emblanch, Y Dudal, C Batiot-Guilhe, Y Travi, and S Gaffet. 2010. "Transit Time Environmental Tracing from Dissolved Organic Matter Fluorescence Properties in Karstic Aquifers. Application to Different Flows of Fontaine de Vaucluse Experimental Basin (SE France) BT Advances in Research in Karst Media.” In , edited by Bartolomé Andreo, Francisco Carrasco, Juan José Durán, and James W LaMoreaux, 143-49. Berlin, Heidelberg: Springer Berlin Heidelberg. https://doi.org/10.1007/978-3-642-12486-0_22.

Carrière, S D., K Chalikakis, C Danquigny, H Davi, N Mazzilli, C Ollivier, and C Emblanch. 2016. “The Role of Porous Matrix in Water Flow Regulation within a Karst Unsaturated Zone: An Integrated Hydrogeophysical Approach.” Hydrogeology Journal, 1905-18. https://doi.org/10.1007/s10040-0161425-8.

Covington, M D, and K A Vaughn. 2018. "Carbon Dioxide and Dissolution Rate Dynamics within a Karst Underflow-Overflow System, Savoy Experimental Watershed, Arkansas, USA.” Chemical Geology. https://doi.org/https://doi.org/10.1016/j.chemgeo.2018.03.009.

Doctor, D H, E C Alexander, M Petrič, J Kogovšek, J Urbanc, S Lojen, and W Stichler. 2006. “Quantification of Karst Aquifer Discharge Components during Storm Events through End-Member Mixing Analysis Using Natural Chemistry and Stable Isotopes as Tracers.” Hydrogeology Journal 14 (7): 1171-91. https://doi.org/10.1007/s10040-006-0031-6.

Dreiss, S J. 1989. "Regional Scale Transport in a Karst Aquifer: 2. Linear Systems and Time Moment Analysis.” Water Resources Research 25 (1): 126-34. https://doi.org/10.1029/WR025i001p00126.

Einsiedl, F, and B Mayer. 2005. "Sources and Processes Affecting Sulfate in a Karstic Groundwater System of the Franconian Alb, Southern Germany.” Environmental Science \& Technology 39 (18): 7118-25. https://doi.org/10.1021/es050426j.

- 2006. "Hydrodynamic and Microbial Processes Controlling Nitrate in a Fissured-Porous Karst Aquifer of the Franconian Alb, Southern Germany.” Environmental Science \& Technology 40 (21): 6697-6702. https://doi.org/10.1021/es061129x.

Emblanch, C, G M Zuppi, J Mudry, B Blavoux, and C Batiot. 2003. “Carbon 13 of TDIC to Quantify the Role of the Unsaturated Zone: The Example of the Vaucluse Karst Systems (Southeastern France).” Journal of Hydrology 279 (1-4): 262-74. https://doi.org/http://dx.doi.org/10.1016/S0022-1694(03)00180-X.

Evans, C, and T D. Davies. 1998. "Causes of Concentration/Discharge Hysteresis and Its Potential as a Tool for Analysis of Episode Hydrochemistry.” Water Resources Research 34 (1): 129-37. https://doi.org/10.1029/97WR01881.

Ford, D, and P Williams. 2007. Karst Hydrogeology and Geomorphology. Chichester, UK: Wiley.

Gabrovšek, F, B Peric, and G Kaufmann. 2018. "Hydraulics of Epiphreatic Flow of a Karst Aquifer.” Journal of Hydrology 560: 56-74. https://doi.org/https://doi.org/10.1016/j.jhydrol.2018.03.019.

Gaillardet, J, I Braud, F Hankard, S Anquetin, O Bour, N Dorfliger, J R de Dreuzy, et al. 2018. "OZCAR: The French Network of Critical Zone Observatories.” Vadose Zone Journal 17. https://doi.org/10.2136/vzj2018.04.0067.

Garry, B, T Blondel, C Emblanch, C Sudre, S Bilgot, A Cavaillou, D Boyer, and M Auguste. 2008. "Contribution of Artificial Galleries to the Knowledge of Karstic System Behaviour in Addition to Natural Cavern Data.” International Journal of Speleology 37 (1): 75-82. https://doi.org/PNR61.

Goldscheider, N, and D Drew. 2007. Methods in Karst Hydrogeology. London, UK: Taylor and Francis.

Helena, B, R Pardo, M Vega, E Barrado, J M Fernandez, and L Fernandez. 2000. “Temporal Evolution of Groundwater Composition in an Alluvial Aquifer (Pisuerga River, Spain) by Principal Component 
Analysis.” Water Research 34 (3): 807-16. https://doi.org/http://dx.doi.org/10.1016/S00431354(99)00225-0.

Jourde, H, N Massei, N Mazzilli, S Binet, C Batiot-Guilhe, D Labat, M Steinmann, et al. 2018. "SNO KARST: A French Network of Observatories for the Multidisciplinary Study of Critical Zone Processes in Karst Watersheds and Aquifers.” Vadose Zone Journal 17. https://doi.org/10.2136/vzj2018.04.0094.

Kazakis, N, K Chalikakis, N Mazzilli, C Ollivier, A Manakos, and K Voudouris. 2018. "Science of the Total Environment Management and Research Strategies of Karst Aquifers in Greece : Literature Overview and Exempli Fi Cation Based on Hydrodynamic Modelling and Vulnerability Assessment of a Strategic

Karst Aquifer.” Science of the Total Environment 643: 592-609. https://doi.org/10.1016/j.scitotenv.2018.06.184.

Labat, D, R Ababou, and A Mangin. 2000. "Rainfall-Runoff Relations for Karstic Springs. Part I: Convolution and Spectral Analyses.” Journal of Hydrology 238 (3-4): 123-48. https://doi.org/10.1016/ S0022-1694(00)00321-8.

Lee, E S, and N C Krothe. 2003. "Delineating the Karstic Flow System in the Upper Lost River Drainage Basin, South Central Indiana: Using Sulphate and $\Delta 34 \mathrm{SSO} 4$ as Tracers.” Applied Geochemistry 18 (1): 145-53. https://doi.org/http://dx.doi.org/10.1016/S0883-2927(02)00067-7.

Maréchal, J C, and D Etcheverry. 2003. "The Use of 3H and $18 \mathrm{O}$ Tracers to Characterize Water Inflows in Alpine Tunnels.” Applied Geochemistry 18 (3): 339-51. https://doi.org/10.1016/S0883-2927(02)001014.

Masse, J P. 1967. “L’Urgonien de Sault (Vaucluse).” Bulletin de La Société Géologique de France S7-IX (4): 495 LP-496. http://bsgf.geoscienceworld.org/content/S7-IX/4/495.abstract.

Mazzilli, N, V Guinot, H Jourde, N Lecoq, D Labat, B Arfib, C Baudement, C Danquigny, L Dal Soglio, and D Bertin. 2017. "KarstMod: A Modelling Platform for Rainfall - Discharge Analysis and Modelling Dedicated to Karst Systems.” Environmental Modelling \& Software. https://doi.org/https://doi.org/10.1016/j.envsoft.2017.03.015.

Moral, F, J J Cruz-Sanjulián, and M Olías. 2008. "Geochemical Evolution of Groundwater in the Carbonate Aquifers of Sierra de Segura (Betic Cordillera, Southern Spain).” Journal of Hydrology 360 (1-4): 28196. https://doi.org/10.1016/j.jhydrol.2008.07.012.

Mudarra, M, and B Andreo. 2011. "Relative Importance of the Saturated and the Unsaturated Zones in the Hydrogeological Functioning of Karst Aquifers: The Case of Alta Cadena (Southern Spain).” Journal of Hydrology 397 (3): 263-80. https://doi.org/https://doi.org/10.1016/j.jhydrol.2010.12.005.

Ollivier, C, C Danquigny, N Mazzilli, and A Barbel-Perineau. 2015. "Contribution of Hydrogeological Time Series Statistical Analysis to the Study of Karst Unsaturated Zone (Rustrel, France) BT Hydrogeological and Environmental Investigations in Karst Systems.” In , edited by Bartolomé Andreo, Francisco Carrasco, Juan José Durán, Pablo Jiménez, and James W LaMoreaux, 27-33. Berlin, Heidelberg: Springer Berlin Heidelberg. https://doi.org/10.1007/978-3-642-17435-3_4.

Poulain, A, A Watlet, O Kaufmann, M Van Camp, H Jourde, N Mazzilli, G Rochez, R Deleu, Y Quinif, and V Hallet. 2018. "Assessment of Groundwater Recharge Processes through Karst Vadose Zone by Cave Percolation Monitoring.” Hydrological Processes 32 (13): 2069-83. https://doi.org/10.1002/hyp.13138.

Puig, J. 1987. "Le Système Karstique de La Fontaine de Vaucluse.” Université d’Avignon et des Pays de Vaucluse.

Rezende Filho, AT, V Valles, S Furian, C M S C Oliveira, J Ouardi, and L Barbiero. 2015. "Impacts of Lithological and Anthropogenic Factors Affecting Water Chemistry in the Upper Paraguay River 
Basin.” Journal of Environmental Quality 44: 1832-42. https://doi.org/10.2134/jeq2015.01.0019.

Sánchez, D, J A Barberá, M Mudarra, B Andreo, and J F Martín. 2017. "Hydrochemical and Isotopic Characterization of Carbonate Aquifers under Natural Flow Conditions, Sierra Grazalema Natural Park, Southern Spain.” Geological Society, London, Special Publications 466 (November): SP466.16. https:// doi.org/10.1144/SP466.16.

Strebel, O, J Böttcher, and P Fritz. 1990. "Use of Isotope Fractionation of Sulfate-Sulfur and Sulfate-Oxygen to Assess Bacterial Desulfurication in a Sandy Aquifer.” Journal of Hydrology 121 (1): 155-72. https:// doi.org/https://doi.org/10.1016/0022-1694(90)90230-U.

Tendil, A J-B, C Frau, P Léonide, F Fournier, J R Borgomano, C Lanteaume, J-P Masse, G Massonnat, and JP Rolando. 2018. "Platform-to-Basin Anatomy of a Barremian-Aptian Tethyan Carbonate System: New Insights into the Regional to Global Factors Controlling the Stratigraphic Architecture of the Urgonian Provence Platform (Southeast France)." Cretaceous Research 91: 382-411. https://doi.org/https://doi.org/10.1016/j.cretres.2018.05.002.

Toran, L, and C E Reisch. 2013. "Using Stormwater Hysteresis to Characterize Karst Spring Discharge.” Groundwater 51 (4): 575-87. https://doi.org/10.1111/j.1745-6584.2012.00984.x.

Toran, L, and E Roman. 2006. "CO2 Outgassing in a Combined Fracture and Conduit Karst Aquifer near Lititz Spring, Pennsylvania.” Geological Society of America Special Papers 404 (January): 275-82. http://specialpapers.gsapubs.org/content/404/275.abstract.

Valles, V, O Ribolzi, A M De Cockeborne, and M Cornieles. 1996. "Presentation de AQUA, Logiciel de Géochimie Appliqué Aux Problèmes Environnementaux.” In Groupe de Réflexion Sur l'Etude de La Solution Du Sol En Relation Avec l'Alimentation Des Plantes, GRESSAP. Montpellier: ORSTOM.

Vesper, D J, W B White, D J Vesper, and W B White. 2004. "Storm Pulse Chemographs of Saturation Index and Carbon Dioxide Pressure: Implications for Shifting Recharge Sources during Storm Events in the Karst Aquifer at Fort Campbell, Kentucky/Tennessee, USA.” Hydrogeology Journal 12: 135-43. https://doi.org/10.1007/s10040-003-0299-8.

Vouillamoz, J M, A Legchenko, Y Albouy, M Bakalowicz, J M Baltassat, and W Al-Fares. 2003. "Localization of Saturated Karst Aquifer with Magnetic Resonance Sounding and Resistivity Imagery." Ground Water 41 (5): 578-86. https://doi.org/10.1111/j.1745-6584.2003.tb02396.x.

Watlet, A, O Kaufmann, A Triantafyllou, A Poulain, J E Chambers, P I Meldrum, P B Wilkinson, et al. 2018. "Imaging Groundwater Infiltration Dynamics in the Karst Vadose Zone with Long-Term ERT Monitoring.” Hydrol. Earth Syst. Sci. 22 (2): 1563-92. https://doi.org/10.5194/hess-22-1563-2018.

White, W B, and E L White. 2005. "Ground Water Flux Distribution between Matrix , Fractures , and Conduits: Constraints on Modeling." Speleogenesis and Evolution of Karst Aquifers 3 (2): 2-6. http://speleogenesis.net/directory/karstbase/publication.php?id=9294.

Williams, P W. 1983. "The Role of the Subcutaneous Zone in Karst Hydrology.” Journal of Hydrology 61 (1): 45-67. https://doi.org/http://dx.doi.org/10.1016/0022-1694(83)90234-2.

Xiang, W, B C Si, A Biswas, and Z Li. 2019. "Quantifying Dual Recharge Mechanisms in Deep Unsaturated Zone of Chinese Loess Plateau Using Stable Isotopes.” Geoderma 337: 773-81. https://doi.org/https://doi.org/10.1016/j.geoderma.2018.10.006. 
